American University Washington College of Law

Digital Commons @ American University Washington College of

Law

Contributions to Books

Scholarship \& Research

2018

\title{
Legal Scholarship and External Critique in EU Law
}

Fernanda Giorgia Nicola Dr.

American UniversityWashington College of Law, fnicola@wcl.american.edu

Daniela Caruso

Boston University School of Law

Follow this and additional works at: https://digitalcommons.wcl.american.edu/facsch_bk_contributions

Part of the International Law Commons

\section{Recommended Citation}

Nicola, Fernanda Giorgia Dr. and Caruso, Daniela, "Legal Scholarship and External Critique in EU Law" (2018). Contributions to Books. 169.

https://digitalcommons.wcl.american.edu/facsch_bk_contributions/169

This Book Chapter is brought to you for free and open access by the Scholarship \& Research at Digital Commons @ American University Washington College of Law. It has been accepted for inclusion in Contributions to Books by an authorized administrator of Digital Commons @ American University Washington College of Law. For more information, please contact kclay@wcl.american.edu. 


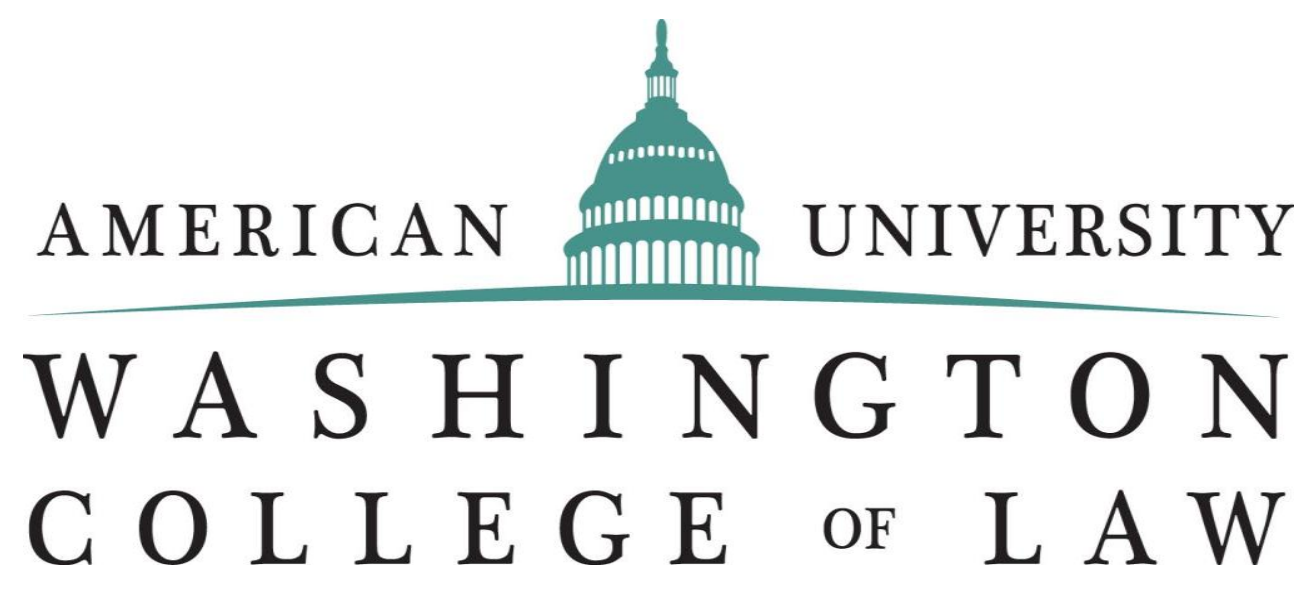

American University Washington College of Law

Washington College of Law Research Paper No. 2016-30

\section{LEgAL SCHOLARSHIP AND EXTERNAL CRITIQUE IN EU LAW}

Daniela Caruso

Fernanda Nicola 


\title{
Legal Scholarship and External Critique in EU Law
}

\author{
DANIELA CARUSO $^{*}$ AND FERNANDA NICOLA ${ }^{*}$
}

\section{Introduction: Nostalgia and Engagement}

Why, readers might wonder, would a group of Croatian legal scholars spearhead this volume? Why would they care, at this specific juncture in the history of EU law, to reflect on a movement-Critical Legal Studies (CLS) — born in the peculiar and utterly American socio-legal context of the 1970s?

Two explanations come to mind. First, nostalgia. Nostalgia explains many types of human behaviour and may have something to do with the genesis of this volume. Contributors Judge Rodin and President Lenaerts, honourable members of the EU Court of Justice (CJEU), were both exposed at a younger age to CLS teachings in the United States. ${ }^{1}$ They remember their encounter with critical legal theory, which freed them from the dogmatic cage of their coursework at home and allowed, for once, exploration of the law's outer boundaries-its implication in power-building, its open-endedness, and its ambivalent relation with the quest for distributive justice. No one ever forgets the travels of one's youth and, in the cleverest minds, intellectual tourism leaves the sweetest of memories.

To be sure, CLS's critique of adjudication-with its insistence on the inextricable link between judicial function and ideology, on the indeterminate nature of

\footnotetext{
* Professor of Law and Jean Monnet Chair, Boston University School of Law.

** Professor of Law, Washington College of Law, American University, Director of the Program on International Organizations, Law and Diplomacy.

1 Koen Lenaerts received his LLM at Harvard Law School in 1978. His LLM paper, written under the supervision of Duncan Kennedy in 1978, was titled 'The "Negative Implications" of the Commerce Clause and "Preemption" Doctrines as Federalism-related Limitations on State Power: A Historical Review' The paper provided an internal critique of the US jurisprudence on the dormant commerce clause. Siniša Rodin received his LLM at Michigan Law School in 1992. In 2002 he visited Cornell Law School and his acquaintance with Mitchel Lasser influenced his choice of readings (most notably the works of Pierre Schlag).
} 
legal arguments, and on politics in the court ${ }^{2}$ — could make these judges deeply uncomfortable today. However, their contributions to this volume give that critique a nod and then quickly move on to safer ground. ${ }^{3}$ Their superior expertise, classical training and explicit identification of firm methodological boundaries in judicial reasoning can reassure the European reader that they have certainly not caught the indeterminacy virus. ${ }^{4}$ With due caution, nostalgia can be both pleasurable and harmless. Gratitude to one's former teachers for their unforgettable lessons is obviously compatible with parting ways, whether geographically or intellectually.

The other explanation for the birth of this volume is more complex, and has to do with a scholarly project that involves not only notable (male) jurists but also prominent (female) academics professionally anchored in the youngest Member State of the European Union. ${ }^{5}$ In one word, we define this ulterior prompt for this volume as 'engagement', legal and political. There are times in history when jurists become particularly aware of their responsibility in shaping the structure of government, in informing the discourse of and about law, and in resisting dangerous political trends. ${ }^{6}$ The Croatian scholars at the helm of this project clearly perceive themselves to be at such a juncture, and are acting accordingly.

Our own contribution to this volume stems, on the one hand, from a deep empathy with the editors' project of engagement and, on the other, from familiarity with the CLS movement in the US. We proceed as follows: section II articulates several ways in which the engaged intellectuals who spearheaded this volume may derive both inspiration and tools from American CLS literature. Section III spotlights one particular CLS tool, known as 'external critique', and outlines its targets-namely the distributive effects of CJEU cases, their uneven impact on different groups, and their implications for justice across class, gender, race, nationality or socio-economic status. Section IV discusses the role of progressive scholars in bringing distributive stakes to the fore and vigorously engaging in the external critique of judgment in Luxembourg. Section V illustrates two CLS points that complicate the work of the legal scholar-distributive ambivalence and legal indeterminacy_-and concludes by reasserting the value of critical scholarship in spite of its unavoidable limitations.

2 Duncan Kennedy, A Critique of Adjudication: Fin de Siècle (Cambridge, Harvard University Press, 1997).

3 See Siniša Rodin, 'Useful Effect of the Framework Decision on the European Arrest Warrant' (in this volume); Koen Lenaerts, 'Discovering the Law of the EU: The European Court of Justice and the Comparative Law Method' (in this volume).

${ }^{4}$ See Lenaerts, ibid (positing that adopting the comparative method enables the court 'to resolve particular gaps, conflicts and ambiguity without embarking on judicial legislation').

5 Croatia joined the EU in 2013. Two of the contributors to this volume are established members of the law faculty of the University of Zagreb: Tamara Ćapeta and Tamara Perišin. Judge Siniša Rodin, co-editor of this volume, was a member of the same law faculty until he joined the CJEU in 2013.

6 Piero Calamandrei, in spite-or perhaps because of-the internal contradictions of his opus, famously exemplifies the 'engaged jurist' in the Italian legal tradition. See Piero Calamandrei, Lo Stato Siamo Noi (Milan, Chiarelettere, 2011). 


\section{EU Law Scholarship as Engagement}

There are at least three ways in which working on EU law in a place like Zagreb is a form of social and political engagement. First, as a scholarly discipline, EU law is naturally poised to challenge established layers of authority in the law faculties of the new(er) Member States. This is because, by definition, no bulwark of academic power could until recently be built around this subject. In EU law, expertise is a prerogative of the young - a fact that allows for novel and inverted hierarchies. A testament to the engagement of Croatian scholars in the EU-national law debate is found in the Dubrovnik Jean Monnet Seminars, which have served as a regular forum for East-West dialogue since 2003. These seminars are known for raising anti-formalist issues and for introducing doctoral students to the role of policy and power in the creation and administration of law. ${ }^{7}$ The proceedings of the Dubrovnik meetings may be published in the prestigious Croatian Yearbook of European Law and Policy - a peer reviewed journal of regional scope and broad ambition. $^{8}$

A second dimension of engagement appears in the operational dynamics of substantive EU law. Teaching and writing about EU law can be a disruptive, critical project not only in relation to the institutional layers of local academia, but also vis-à-vis the substance of Member States' law. Because the EU demands the approximation of domestic laws around the time of accession and at each new stage of integration, the process of harmonisation forces scholars, judges and legislators to rethink and question the rationale of national rules. ${ }^{9}$ The resulting pressure for legal reform brings existing privileges and unspoken judicial policies to the surface. ${ }^{10}$ Legal formalism is no excuse for resisting reform, and legal change must be fought for or resisted on the basis of clear distributive arguments. In other words, in the aftermath of accession, EU law often is critique. It unveils false necessities in Member States' legal discourse and may identify winners and losers in consolidated domestic legal practices. ${ }^{11} \mathrm{~A}$ loose analogy with CLS is easy

7 See eg Adam Lazowski, 'Who's Got the Power? Division of Competence in EU Membership Acquis', paper presented at the Dubrovnik seminar, www.pravo.unizg.hr/_download/repository/ Dubrovnik_2016_-_Programme.pdf.

8 Croatian Yearbook of European Law and Policy, 'Home' (2016) www.cyelp.com/index.php/cyelp.

${ }^{9}$ Christian Joerges, 'The Europeanisation of Private Law as a Rationalisation Process and as a Contest of Disciplines-An Analysis of the Directive on Unfair Terms in Consumer Contracts' (1995) 3 European Review of Private Law 3.

10 To name just one example, the Product Liability Directive proved hard to transpose in the Member States, because it mobilised corporate lobbying and threatened to undo the quiet pro-consumer revolution conducted by judges since the 1960s. Daniela Caruso, 'The Missing View of the Cathedral' (1997) 3 European Law Journal 3.

11 Gunther Teubner, 'Legal Irritants: Good Faith in British Law or How Unifying Law Ends Up in New Differences' (1998) 61 Modern Law Review 11. See also Pierre Legrand, 'On the Singularity of Law' (2006) 47 Harvard International Law Journal 517, 520 (discussing, by way of example, the distributive impact of EU-wide sanitary standards on small enterprises and farmers in Poland who are excluded from the new production chains of the internal market). 
to establish here. Two defining features of the CLS movement are the denunciation of false necessity in legal deduction and the focus on the distributive and redistributive consequences of legal rules. These very features happen also to be natural by-products of early-stage Europeanisation. CLS was a militant project in the American legal academy of the 1970s and continues to display defiant and utopian features ${ }^{12}$ in the many corners of the world where it has seeped under various guises. ${ }^{13}$ It is therefore an inspiration for those scholars who, like the editors of this volume, perceive their engagement with EU law as part of a larger project of justice. ${ }^{14}$

Third, and most importantly, this volume reflects a desire to subject EU law itself to a critical rethinking. It is clear by now that the Europeanisation of law has brought about its own set of questionable dogmas: the centrality of the individual, ${ }^{15}$ a structural blindness to intra-EU distribution, ${ }^{16}$ a strong market paradigm that often crowds out alternate visions, ${ }^{17}$ and a practical indifference to the geopolitical externalities of the project. ${ }^{18}$ From the standpoint of Croatian scholars in particular, the EU's own role in such post-accession catastrophes as the Euro-zone crisis and the deaths of thousands of migrants in the Mediterranean waters requires closer scrutiny at the very least. ${ }^{19}$ When the dust of accession settles and the promises of peace and prosperity fail to materialise, scholarly engagement necessarily takes a sceptical turn and begins to contemplate whether foundational concepts of EU law might themselves be vehicles of distributive and ideological regression. Here, EU law is not the critique. EU law is its object.

The propensity to engage in a sustained critique of EU law marbles several contributions in this volume and certainly animates this chapter. This generally critical stance takes the present stage of legal Europeanisation as a fact and aims

12 Roberto Unger, The Critical Legal Studies Movement 2nd edn (Cambridge, Harvard University Press, 1983) (emphasising the often unspoken utopian strand in CLS).

13 See eg Sylvia Wairimu Kang'ara, 'Beyond Bed and Bread: Making the African State through Marriage Law Reform-Constitutive and Transformative Influences of Anglo-American Legal Thought' (2012) 9 Hastings Race \& Poverty Law Journal 353.

${ }^{14}$ The Croatian Yearbook self-identifies as a critical project and explicitly aims to embed legal questions 'in a wider political, economic and social context', Yearbook (n 8).

15 See Joseph HH Weiler, 'Van Gend en Loos: The Individual as Subject and Object and the Dilemma of European Legitimacy' (2014) 12 International Journal of Constitutional Law 94; Daniela Caruso, 'Limits of the Classic Method: Positive Action in the European Union after the New Equality Directives' (2003) 44 Harvard International Law Journal 331.

16 Damjan Kukovec, 'Law and the Periphery' (2015) 21 European Law Journal 406; Marija Bartl, 'The Way We Do Europe: Subsidiarity and the Substantive Democratic Deficit' (2015) 21 European Law Journal 23; Fernanda Nicola, 'Invisible Cities in Europe' (2012) 35 Fordham International Law Journal 1282.

17 Marija Bartl, 'Internal Market Rationality, Private Law and the Direction of the Union: Resuscitating the Market as the Object of the Political' (2015) 21 European Law Journal 572.

18 See, eg, Daniela Caruso and Joanna Geneve, 'Trade and History: The Case of EU-Algeria Relations' (2015) 33(1) Boston University International Law Journal.

19 Iris Goldner Lang, 'Is There Solidarity on Asylum and Migration in the EU?' (2013) 9 Croatian Yearbook of European Law and Policy 1. 
to make full use of the possibilities for political and social justice it can currently support, but at the same time it decries its many structural and dynamic drawbacks. In doing so, this critical project borrows liberally from CLS without fear of misreading or misappropriation. Irreverence in this context is a feature, not a bug. ${ }^{20}$ The CLS toolkit is clearly useful to European scholars, but there is no pretence here of fidelity to the original CLS conception. ${ }^{21}$ Transformations can be productive on EU soil, and there is no reason not to utilise, albeit in a different epistemic environment, the motivational force of lessons drawn from far-away places or times. ${ }^{22}$

The CLS toolkit can be embraced selectively; its tenets disassembled and recomposed at leisure. For instance, the methodology of internal critique works best when EU legal deduction is simply flawed or when interpretive results presented as necessary are no more plausible than the road not taken. ${ }^{23}$ External critique is useful when decisions made at any node of the EU system lead to distributively questionable outcomes. The critique of rights-another staple of CLS scholarship ${ }^{24}$ _easily takes apart such constructs as EU citizenship ${ }^{25}$ and market access, ${ }^{26}$ which may lead to a deficit of substantive justice. ${ }^{27}$

What CLS stands for, when translated onto the operational level of EU legal scholarship, is a thorough rethinking of the project of integration through law in any of its formants, ${ }^{28}$ not just the judicial one. ${ }^{29}$ With no pledge of adherence to the CLS archetype and no obvious political direction, this loosely critical posture may come across to CLS founders as inchoate and even spineless-in other words, as a non-movement. In the current landscape of EU legal scholarship, critique is indeed piecemeal and disaggregated. If it is a project at all, it is one of scattered resistance with no flag or army. Yet, as the following sections illustrate,

20 Umberto Eco, Misreadings (San Diego, Harcourt Brace, 1993).

${ }^{21}$ See, eg, Máximo Langer, 'From Legal Transplants to Legal Translations: The Globalization of Plea Bargaining and the Americanization Thesis in Criminal Procedure' (2004) 45 Harvard International Law Journal 1.

22 See Diego López Medina, 'Por Qué Hablar de Una “Teoría Impura del Derecho” Para América Latina?' in Daniel Bonilla Maldonado (ed), Teoría del Derecho y Trasplantes Jurídicos (Bogotá, Siglo del Hombre, 2009) (explaining why misreadings need not be corrected).

23 Gráinne De Búrca, 'The Road Not Taken: The EU as a Global Human Rights Actor' (2011) 105 American Journal of International Law 649.

${ }^{24}$ See Duncan Kennedy, 'The Critique of Rights in Critical Legal Studies’ in Wendy Brown and Janet Halley (eds), Left Legalism/Left Critique (Durham NC, Duke University Press, 2002).

25 Joseph Weiler, 'Editorial: Individuals and Rights-The Sour Grapes' (2010) 21(2) European Journal of International Law 277.

${ }^{26}$ Damjan Kukovec, 'Economic Law, Inequality and Hidden Hierarchies on the EU Internal Market' (2017) 38(1) Michigan Journal of International Law.

27 Dimitry Kochenov, Gráinne de Búrca and Andrew Williams (eds), Europe's Justice Deficit? (Oxford, Hart Publishing, 2015).

28 Rodolfo Sacco, 'Legal Formants: A Dynamic Approach to Comparative Law' (1991) 39 American Journal of Comparative Law 1.

29 Bryant Garth, 'The Florence Access-to-Justice Project in Law and in Context: Mauro Cappelletti as Importer, Exporter, and Academic Entrepreneur' (2016) Annuario di Diritto Comparato 13. 
EU law can be better analysed, understood and perhaps transformed when observed through CLS-tinted glasses.

We prioritise here external critique over the many other tools in the CLS kit. By external critique, we mean the scholarly activity of highlighting the distributive stakes - and therefore the political and ideological dimensions-of legal disputes adjudicated by the CJEU. ${ }^{30}$ The importance of external critique lies in the fact that adjudication plays a role in eliminating or maintaining privilege, or class and race inequalities. ${ }^{31}$ In comparison to the tool of internal critique, which focuses on logical inconsistencies in judicial reasoning and reveals the often ambivalent results of deduction, external critique is a harder sell in Europe, ${ }^{32}$ given the still widespread belief in the importance of isolating the judicial function from concern with the political impact of each case's outcome. ${ }^{33}$ We nonetheless hope to show first, that distributive arguments are as a matter of fact not foreign to judicial reasoning in Luxembourg ${ }^{34}$ and, second, that scholarly commentary on the correctness of such arguments, whether expressed or silently woven into the fabric of judgments, is a necessary and important part of the life of engaged jurists. ${ }^{35}$

\section{Distributive Arguments in Adjudicatory Practice}

Whether judges in Luxembourg, or elsewhere, should take into account the larger distributive consequences of their decisions remains an unsettled question. ${ }^{36}$ Prominent scholars object to distributive justice as a goal of adjudication because of the conviction that (re)distribution is more efficiently achieved through taxation

30 The distinction between internal and external perspectives in law predates the CLS movement. See Brian Z Tamanaha, 'The Internal/External Distinction and the Notion of a "Practice" in Legal Theory and Sociolegal Studies' (1996) 30 Law and Society Review 163; Charles L Barzun, 'Inside-Out: Beyond the Internal/External Distinction in Legal Scholarship' (2015) 101 Virginia Law Review 1203.

31 Marc Galanter, 'Why the "Haves" Come Out Ahead: Speculations on the Limits of Legal Change' (1974) 9 Law and Society Review 95; Duncan Kennedy, Legal Reasoning: Collected Essays (Aurora CO, Davies Group Publishers, 2008).

32 See Siniša Rodin, 'A Metacritique of the Court of Justice of the EU' (2016) 4 Il Diritto dell'Unione Europea 193.

33 This belief is firmly held or at least clearly deployed also in progressive circles. See eg Michelle Everson, 'An Exercise in Legal Honesty: Rewriting the Court of Justice and the Bundesverfassungsgericht' (2015) 21 European Law Journal 21.

34 Below s III (discussing distributive principles in the E Fritz case).

35 Below ss IV and V.

36 The points summarily articulated in this section are further explored in Daniela Caruso, 'Fairness at a Time of Perplexity: The Civil Law Principle of Fairness in the Court of Justice of the European Union' in Stefan Vogenauer and Stephen Weatherill (eds), General Principles of Law: European and Comparative Perspectives (Oxford, Hart Publishing, 2017) 329. 
and other forms of transfers, as opposed to judgment in discrete disputes. ${ }^{37}$ But in equally reputable milieus, courts are expected to redress, within the boundaries of judicial discretion, the predicaments of situationally disadvantaged parties. ${ }^{38}$ This is because-among other reasons - a distribution-insensitive mode of adjudication would not be neutral, but rather bound to produce regressive results that defy common notions of justice. ${ }^{39}$

In European circles, there is a pervasive assumption that distributive arguments do not belong in judicial reasoning. ${ }^{40}$ Most courts, aiming to preserve legitimacy and authority, generally cling to the language of internal coherence; to this goal, they stay within the boundaries of doctrinal abstraction and formalism, or at most put forth an even-handed balancing of distributively neutral policies (efficiency, judicial economy, protection of expectations, etc) ${ }^{41}$ CLS notoriously challenges this judicial posture on both normative $e^{42}$ and descriptive grounds. ${ }^{43}$

In an American CLS perspective, a paradigmatic example of judicial responsiveness to distributive considerations is found in Justice Brennan's opinion in Penn Central $v$ New York. ${ }^{44}$ The facts are well known and are only summarily recalled here. Appellants, owners of Penn Central Station, had sought a permit to build above the existing station's structure, but because of a zoning regulation aimed at preserving historic landmarks, their request was denied. The appellants then sought monetary compensation. In their view, the denial of the permit resulted in the taking of their jus aedificandi and in a significant depreciation of real estate

\footnotetext{
37 Louis Kaplow and Steven Shavell, 'Why the Legal System is Less Efficient than the Income Tax in Redistributing Income' (1994) 23 Journal of Legal Studies 667.

38 Lee Anne Fennell and Richard McAdams, 'The Distributive Deficit in Law and Economics' (2016) 100 Minnesota Law Review 1051 (providing a thorough critique of the assumption that taxation is always a preferable strategy for wealth redistribution).

39 See Robert Hale, 'Coercion and Distribution in a Supposedly Non-Coercive State' (1923) Political Science Quarterly 470.

${ }^{40}$ See Fernanda Nicola, 'Transatlanticisms: Constitutional Asymmetry and Selective Reception of US Law and Economics in the Formation of European Private Law' (2008) 16 Cardozo Journal of International and Comparative Law 101 (arguing in favour of an open analysis of distributive consequences in the CJEU's private law judgments).

${ }^{41}$ It is often the case that with judicial balancing, by now a feature of adjudication around the globe, mere lip service is paid to conflicting considerations, but no real solace can be found against regressive outcomes of law and policy choices. Duncan Kennedy, 'Three Globalizations of Law and Legal Thought' in David Trubek and Alvaro Santos (eds), The New Law and Development: A Critical Appraisal (Cambridge, Cambridge University Press, 2006). See also Mitchel Lasser, 'Fundamentally Flawed: The CJEU's Jurisprudence on Fundamental Rights and Fundamental Freedoms' (2014) 15 Theoretical Inquiries in Law 229.

42 Kennedy (n 2).

43 For the argument that, as a matter of positive law, redistributive motives are already pervasive in all corners of adjudication, including private law, see Duncan Kennedy, 'Distributive and Paternalist Motives in Contract and Tort Law, with Special Reference to Compulsory Terms and Unequal Bargaining Power' (1982) Maryland Law Review 563. See also Aditi Bagchi, 'Distributive Justice and Contract' in Gregory Klass, George Letsas and Prince Saprai (eds), Philosophical Foundations of Contract Law (Oxford, Oxford University Press, 2013).

44 Penn Cent Transp Co v City of New York, 438 US 104 (1978).
} 
value. Famously, Brennan saw things otherwise. In his view, the appellants should only be thankful for the City's time-honoured practice of preserving historic landmarks from disorderly urban development. In fact, strict zoning in the area around the station was precisely the reason for the enormous value of Penn Central's property. In the balancing of property rights against public interest, it therefore became clear that the appellants derived great advantage from the very regulatory practice they now deemed harmful and deserved, as a consequence, no compensation. ${ }^{45}$

The mode of judicial reasoning adopted in Penn Central may strike some European observers as excessively open-ended, but it is hard to see how the dispute could be seriously resolved without resorting to Brennan's distributive logic. The case shows that a lucid consideration of benefits and harms is not beyond the realm of judicial functions, but is rather essential to an intelligent adjudication of specific cases. Is this type of reasoning off limits in Luxembourg? Interestingly, it is not. ${ }^{46}$

Take, for instance, E Friz, a ground-breaking case decided at the dawn of this decade by the CJEU. ${ }^{47}$ In brief, in 1991 Mr von der Heyden received an unsolicited visit by a tax consultant who convinced him to invest, together with other partners, in the modernisation of decrepit real estate in Berlin. For contracts concluded in this haphazard fashion, the EU door-step selling directive grants consumers a right to repent, ie to cancel the deal in a period of no less than seven days from due notice of this right. ${ }^{48}$ If the consumer receives no such notice-as was the case in E Friz - the possibility to cancel lasts much longer. ${ }^{49}$ Accordingly, $\mathrm{Mr}$ von der Heyden withdrew from the partnership in 2002, after a period of over 10 years, hoping to recoup the full value of his investment on restitutionary grounds. The partnership, however, refused to refund $\mathrm{Mr}$ von der Heyden in full and asked

45 ibid 147.

${ }^{46}$ It is often in the AG's opinion that one finds a more explicit engagement with the distributive consequences of the Court's choices. Take for instance the opinion of Advocate General Eleanor Sharpston, aimed at striking down a reverse discriminatory scheme in Belgium. Case C-212/06 Govt of the French Cmty v Flemish Govt [2008] ECR I-1683. Here, Sharpston openly explains that an uneven allocation of resources might be simply discriminatory, and therefore illegal, or it might be aimed to promote growth in underdeveloped territories. In either case, Sharpston makes the point that European judges are well situated to understand the progressive or regressive impact of a domestic regulatory scheme on different local and transnational communities. See ibid para 155. For reasons investigated in depth especially by Mitchel Lasser, Judicial Deliberations (Oxford, Oxford University Press, 2009), this position is seldom taken by the Court so openly.

47 Case C-215/08 E Friz GmbH v Carsten von der Heyden [2010] ECR I-2947. The facts and the law of the E Friz case have been thoroughly analysed by other scholars, making a full summary here redundant. See Martijn Hesselink, 'The General Principles of Civil Law: Their Nature, Roles and Legitimacy' in Dorota Leczykiewicz and Stephen Weatherill (eds), The Involvement of EU Law in Private Law Relationships (Oxford, Hart Publishing, 2013) 131.

48 Dir 85/577/EEC.

49 Case C-481/99 Heininger v Bayerische Hypo- und Vereinsbank AG [2001] ECR I-09945; Case-412/06 Annelore Hamilton $v$ Volksbank Filder eG [2008] ECR I-02383 (discussing the issue of limitation on the time for repentance). 
instead that he pay his share of the steep losses suffered over the years. This result would comply with German law and in particular with the judicial principle of 'defective partnership', duly highlighted for the CJEU by AG Trstenjak in her opinion. ${ }^{50}$

The language used by the Court to endorse the latter result was unmistakably sensitive to distributive concerns. ${ }^{51}$ In 2010, two full years into the financial crisis, consumers all over Europe and beyond shared Mr von der Heyden's desire to walk back from improvident investments. ${ }^{52}$ The E Friz judges were surrounded by news of pervasive financial disasters, and were constantly reminded that the consequences of poor financial market regulation would hit some pockets of the EU population much more heavily than others. Apportioning losses fairly, ie protecting those who were hopelessly stuck with the partnership from the sudden flight of those who could withdraw their membership, seemed to be what justice required. Interestingly, the Court went beyond mere judicial necessity, and openly appealed to solidarity between those who could flee and those left behind in the quagmire of financial disaster. It is at least plausible that the judges could see the analogy between the uneven distribution of losses inside the E Friz partnership on one hand, and Europe's larger inequities on the other: the widening of the spreads, the plight of the unemployed and the predicament of the PIIGS (Portugal, Ireland, Italy, Greece and Spain), at that time haunted by serious debt restructuring problems. In the midst of sobering reflections on law's complicity in perpetuating Europe's inequalities, it may be important to take stock of narrow, but clear, progress through law. ${ }^{53}$

E Friz confirms that in Luxembourg, whenever an interpretive gap leaves the judge room to manoeuvre, a lucid assessment of circumstances and distributive considerations may precede and guide the decision-making process. The case says nothing, however, on the normative desirability of such arguments inside the court-a point dear to CLS founders. ${ }^{54}$ Some contributions in this volume directly tackle the argument that judges should engage systematically and openly in distribution-sensitive argumentation. ${ }^{55}$ We take no stance on such a point in these pages. History is replete with situations in which mere judicial adherence to formalism or to distribution-opaque legal arguments produces results which are

${ }^{50}$ E Friz (n 47).

51 ibid.

52 AG Trstenjak pointed out that 'Investment in [junk] property, which Germans opted for primarily on account of the resultant tax benefits, has often failed to deliver the expected results, and investors have therefore looked for ways of terminating those investments by relying inter alia on the Community directives concerning consumer protection'. E Friz (n 47) para 3.

53 See Ugo Mattei and Fernanda Nicola, 'A "Social Dimension" in European Private Law?: The Call for Setting a Progressive Agenda' (2006) 41 New England Law Review 1.

${ }^{54}$ Duncan Kennedy, 'Proportionality and 'Deference' in Contemporary Constitutional Thought' (in this volume).

${ }^{55}$ For a nuanced and profound discussion of this point in this volume, see Tamara Ćapeta, 'Ideology and Legal Reasoning at the European Court of Justice', s V, 'Conclusions', in this volume. cf Kennedy, 'Role of Courts' (n 54); and Lenaerts (n 3) (espousing radically different visions of the role of ideology in the subjective experience of judging). 
highly desirable from the perspective of substantive justice. It is not our purpose to challenge this type of judicial work on ethical grounds-at least not here.

Our argument here is rather aimed at informing European legal scholarship only (la doctrine), in the hope that a feedback loop between judicial and academic milieus may ultimately lead to substantively progressive outcomes in Luxembourg as well as in the EU's legislative and administrative fora.

\section{External Critique: The Role of European Scholars}

As noted by Pierre Schlag, judges are often excessively narrow in their definition of a dispute's context. ${ }^{56}$ Academic scholarship, on the other hand, is not bound by the built-in constraints of judicial activity nor by the time pressure under which European judges are compelled to decide. Scholars have the necessary institutional freedom and research capabilities to weave together the different narratives surrounding each case, to identify the perspectives of possible winners and losers, and to focus on the broader distributive consequences of a judgment in Luxembourg. ${ }^{57}$

An external critique of EU adjudication is essential to ensure that judicial decision-making and its often obscure distributive consequences are known and understood, not only in lawyers' circles but also in civil society, where choices of broader political salience should be made. ${ }^{58}$ This type of scholarly activity is continually needed not only to decipher the reasoning behind technical judicial language, ${ }^{59}$ but also to make explicit the law-making by-products of judicial dispute resolution. ${ }^{60}$ In addition, European scholarship is an important site of transnational legal theory - a field now undergoing intense critical scrutiny and major transformations, including greater historical self-awareness and global reach. ${ }^{61}$

56 See Pierre Schlag, 'On Textualist and Purposivist Interpretation (Challenges and Problems)' (in this volume) (portraying judges and lawyers as engaged in 'a fairly localised and discrete juridical mission').

57 See Bill Davies and Fernanda Nicola (eds), EU Law Stories: Contextual and Critical Histories of European Jurisprudence (Cambridge, Cambridge University Press, 2017) (aiming to offer careful accounts of the effects of the CJEU decisions for particular litigants in each case).

58 See Bartl (n 16).

59 Phillipe Jestaz and Christophe Jamin, La Doctrine (Paris, Dalloz, 2004).

60 See Daniel R Kelemen, Eurolegalism: The Transformation of Law and Regulation in the European Union (Cambridge, Harvard University Press, 2011).

61 See Fernanda Nicola, 'Critical Legal Histories in EU Law' (2013) 28(5) American University International Law Review 1173; William Twining, 'Globalisation and Legal Scholarship' (Nijmegen/Tilburg, Wolf Legal Publishers, 2009). 
The external critique of adjudication does not figure predominantly in the corpus of EU law scholarship. ${ }^{62}$ Its relative scarcity may be due to a habit of respect for judicial function, or to the widespread belief that legislation, rather than adjudication, is the proper forum for redressing material inequities. ${ }^{63}$ It is also the case that external critique of judicial reasoning is less in tune with the civil law tradition, in which judges are not perceived as 'culture heroes [or] parental figures', but rather as civil servants, ie riders 'of a machine built and operated by legislators' ${ }^{64}$ The paucity of scholarly critique grounded in distributive concerns prevents the emergence of a robust, sustained exchange between scholars and the bench that is common in other judicial cultures. ${ }^{65}$ The landscape is changing, however, and the Court has experienced deep transformations over its 60 years of existence. ${ }^{66}$ The fact that the Court is now staffed by a transnational legal elite and its bureaucracy ${ }^{67}$-immersed in comparative methodologies and moulded by a plurality of legal influences ${ }^{68}$ — should facilitate a more fruitful conversation between scholars and the judicial branch. ${ }^{69}$

To be sure, powerful critiques have been deployed against the Court of Justice on grounds other than distribution. ${ }^{70}$ Scholars have often demanded increased argumentation and express weighing of competing policies. ${ }^{71}$ They have also engaged in internal critiques aimed at denouncing the Court's formalism,

62 There are, of course, prominent exceptions. See eg Hans-W Micklitz 'Mohamad AzizSympathetic and Activist, But Did the Court Get it Wrong?' in Anna Södersten and Joseph Weiler (eds), Where the Court Gets it Wrong (Florence, European Constitutional Law Network, 2013) http:// www.ecln.net/tl_files/ECLN/Florence $\% 202013 /$ Micklitz $\% 20-\% 20$ The $\% 20$ ECJ\%20gets\%20it $\% 20$ wrong\%20Aziz-30-11-14.pdf.

${ }^{63}$ Helena Alviar García, 'Distribution of Resources Led by Courts: A Few Words of Caution' in Helena Alviar García, Karl Klare, and Lucy Williams (eds), Social and Economic Rights in Theory and Practice: Critical Inquiries (London and New York NY, Routledge, 2014).

64 See John Henry Merryman, The Civil Law Tradition: An Introduction to the Legal Systems of Europe and Latin America 3rd edn (Redwood City CA, Stanford University Press, 2007) 37.

65 See Alexandra Braun, Giudici e Accademia nell' Esperienza Inglese: Storia di un Dialogo (Bologna, il Mulino, 2006).

66 See Allan Rosas and others (eds), The Court of Justice and the Construction of Europe: Analyses and Perspectives on Sixty Years of Case-Law (The Hague, Asser Press, 2013).

67 See Mathilde Cohen, 'Judges or Bureaucrats' in Davies and Nicola (n 57) 58.

68 See Fernanda Nicola, 'National Legal Traditions at Work in the Jurisprudence of the European Court of Justice' (2016) 64 American Journal of Comparative Law 865.

69 See Koen Lenaerts and Kathleen Gutman, 'The Comparative Law Method and the European Court of Justice: Echoes across The Atlantic (2016) 64 American Journal of Comparative Law 841; Nicola (n 68); and Mitchel Lasser, 'Decoding the European Judicial Appointments Debates' (in this volume).

${ }^{70}$ See, by way of example only, Hjalte Rasmussen, On Law and Policy in the European Court of Justice: A Comparative Study in Judicial Policymaking (Dordrecht, Martinus Nijhoff, 1986); Damian Chalmers, "The European Court of Justice Has Taken on Huge New Powers as "Enforcer" of the Treaty on Stability, Coordination and Governance. Yet its Record as a Judicial Institution Has Been Little Scrutinised' http://blogs.lse.ac.uk/europpblog/2012/03/07/european-court-of-justice-enforcer/.

${ }^{71}$ Joseph Weiler, 'Epilogue: The Judicial Après Nice' in Gráinne De Búrca and Joseph Weiler (eds), The European Court of Justice (Oxford, Oxford University Press, 2001) 215. Vlad Perju, 'Reason and Authority in the European Court of Justice' (2009) 49 Virginia Journal of International Law 307. 
identifying its incoherent use of legal ontologies, and deconstructing its reasoning from within. ${ }^{72}$ Yet, no matter how thoroughly argued and internally coherent, a judicial opinion may produce regressive distributive effects that need to be clarified in order to be redressed in a timely manner. By the same token, a judicial opinion may have inconspicuous progressive outcomes, which may remain sporadic in application if not sufficiently highlighted in commentary and then generalised through law and policy. It is the task of scholars across a range of social sciences to engage in this type of analysis.

In our view, legal scholarship should embrace the task of external critique through three different moves. The first consists in emphasising the distributive stakes of each judgment (a). ${ }^{73}$ The second is to take a position in support of the marginalised groups that may be saddled with the regressive distributive consequences of a judicial decision (b). A third move engages with deeper political and economic choices, and aims to achieve a more egalitarian, democratic and utopian society (c).

\section{A. Foregrounding the Distributive Stakes}

Through the lens of positive sociology functionalism, ${ }^{74}$ scholars can highlight which groups or constituencies are impacted by the new allocation of rights and privileges that result from each judgment. This can be done through interdisciplinary, empirical or archival work. Jurists may have to borrow from other social sciences or engage directly in detective work in order to gain a broader sense of the consequences of judicial decisions, which extend beyond the perspective of the parties of any given case. ${ }^{75}$ A lesson dear to the CLS movement ${ }^{76}$ but grounded in the earlier tradition of legal realism, ${ }^{77}$ is that distributive effects are intrinsic

72 Sacco (n 28); Siniša Rodin, 'Les effets horizontaux du droit de l'Union européenne' in Antonio Tizzano et al (eds) La Cour de justice de l'Union européenne sous la présidence de Vassilios Skouris (20032015) 491.

${ }^{73}$ See Duncan Kennedy, 'The Stakes of Law, or Hale and Foucault!' (1991) 14 Legal Studies Forum 327.

${ }^{74}$ See Fernanda Nicola, 'Family Law Exceptionalism in Comparative Law' (2011) 58 American Journal of Comparative Law 777 (explaining the distinction between social purpose and positive sociology functionalism).

75 See Karl Llewellyn, 'A Realistic Jurisprudence-The Next Step' (1930) 30 Columbia Law Review 431.

76 See especially Kennedy (n 73).

77 According to David Kennedy, A World of Struggle: How Power Law, and Expertise Shape Global Political Economy (Princeton NJ, Princeton University Press, 2016), the link between law and distribution was made particularly explicit in US legal thought by the following writings: Oliver Wendell Holmes, 'The Path of the Law' (1897) 10 Harvard Law Review 457; Wesley Hohfeld, 'Some Fundamental Legal Conception as Applied in Judicial Reasoning' (1913) 23 Yale Law Journal 16; Robert Hale, 'Coercion and Distribution in a Supposedly Non-coercive State' (1923) 38 Political Science Quarterly 470. 
to legal rules and that ' $[1]$ aw is present whenever gains are distributed, facilitating their aggregation or ensuring their dispersion. ${ }^{78}$

Take the liberalisation of education in the EU for instance-a timely topic in light of the potentially steep costs of Brexit. ${ }^{79}$ Since the 1990s, England experienced a significant influx of EU students entitled by EU law to UK national treatment with respect to both tuition fees and maintenance grants. It was in this context that the CJEU, with its decision in Bidar, ${ }^{80}$ precipitated a political backlash. Denis Bidar, a French national, entered the UK to complete his secondary education and never had recourse to social assistance. In 2001, when he began to study economics at University College London, he received assistance for his tuition fees, but his application for financial aid to cover his housing costs in London was refused on the ground that he was not sufficiently settled in the UK. Seized with a preliminary question, in 2005 the CJEU held that, given Mr Bidar's 'genuine link' with the UK, he could not be treated as a 'grant-tourist' and as such discriminated against. He would therefore be able to receive the housing subsidy. The court was well aware of the consequences this decision would have for the UK education system. Not surprisingly, in the aftermath of Bidar, the UK ramped up its residency requirements to three years for assistance seekers in similar situations. ${ }^{81}$ Some scholars applauded Bidar as a progressive decision, enabling internal free movement and affirming the principle of nondiscrimination, and praised the Court for putting a premium on 'residence, integration and solidarity: the longer the migrants are resident in the host State, the more integrated they are in the society of the host State in terms of benefits. ${ }^{82}$ Others, however, condemned the regressive distributive consequences of this judgment in particular, and of the EU education saga in general. For instance, Gisella Gori noted that certain states, namely the UK and Belgium, were 'net importers of students' in the context of European education mobility. According to Gori this was, in such states, a matter of public finance: broadening the class of housing assistance recipients would shift the funding of education from the private sector (via loans) to tax payers' contributions (via grants). ${ }^{83}$

The policy implications of Bidar appear equally regressive if examined through the lens of local government. Bidar's housing subsidy, allocated to

\footnotetext{
78 David Kennedy, ibid 204.

79 See Sir Stephen Wall, 'Leaving the EU?' (2016) 22 European Public Law 57. See also Steve Peers, 'The Final UK/EU Renegotiation Deal: Legal Status and Legal Effect' (2016) EU Law Analysis http:// eulawanalysis.blogspot.com/2016/02/the-final-ukeu-renegotiation-deal-legal.html.

80 Case C-209/03 Bidar v London Borough of Ealing [2005] ECR I-2119.

${ }^{81}$ Michael Dougan, 'Fees, Grants, Loans and Dole Cheques: Who Covers the Cost of Migrant Education within the EU?' (2005) 42 Common Market Law Review 943, 972; Gareth Davies, “'Any Place I Hang My Hat?” or: Residence is the New Nationality’ (2005) 11 European Law Journal 43.

82 See Catherine Barnard, 'Of Students and Babies' (2005) 64 Cambridge Law Journal 560, 563. See also Catherine Barnard, 'Note on Bidar' (2005) 42 Common Market Law Review 1465.

83 See Gisella Gori, 'Mademoiselle Gravier and Equal Access to Education: Success and Boundaries of European Integration' in Davies and Nicola (n 57) 446 (at least in the UK).
} 
students residing in the Ealing Borough, had a precise redistributive aim. Ealing is located in West London and is populated in large part by non-affluent and immigrant people. ${ }^{84}$ The resident subsidy for students in that particular borough was probably aimed at helping certain vulnerable groups such as the children of Polish, Caribbean and African immigrants rather than foreigners. But in the aftermath of Bidar, housing allowances to residents going to London universities became substantially lower with likely negative consequences for the intended beneficiaries of the subsidy.

\section{B. Taking a Stance}

The second step in our external critique should enable scholars to explore the politics of judicial decision-making. Jurists know well that the doctrinal and social effects of each case are deeply intertwined. Even though law remains relatively autonomous, scholars can show how a particular interpretation of standing requirements, ${ }^{85}$ free movement rights, or of a liability regime can have politically salient implications and favour certain groups at the expense of others. Take for instance Gonzalez Sanchez, ${ }^{86}$ a hotly contested and arguably conservative decision of the ECJ: in this judgment the Court, through an activist interpretation of relevant rules, denied consumers who had contracted Hepatitis $C$ through blood transfusions the possibility of suing their healthcare providers, and thus let them bear their own costs. Compare this case with Océano Grupo ${ }^{87}$ a decision widely acclaimed by pro-consumer advocates. Here, two Spanish sellers sued five buyers for unpaid sums, due under a contract of adhesion, for the sale of encyclopaedias. The ECJ famously allowed a Spanish court to declare the term void of its own motion, setting aside the sellers' argument that this procedural matter should be determined by internal law only. It is important to note, in this regard, that while in cases like Gonzalez Sanchez or Océano Grupo the progressive or regressive distributive consequences of the Court's holding are obvious, in others they remain rather indeterminate and that, given the nature of EU law, the Court's adjudication on legal questions may not have a clear distributive impact. ${ }^{88}$ In such cases it is all the more imperative that scholars point out the distributive ambivalence of the Court's pronouncements. ${ }^{89}$

${ }^{84}$ See History of Ealing Borough available at https://www.ealing.gov.uk/site/.

85 See Andrea Pezza and Roberto Mastroianni, 'Striking the Right Balance: Limits on the Right to Bring an Action Under Article 263(4) of the Treaty on the Functioning of the European Union' (2015) 30 American University International Law Review 743.

${ }^{86}$ Case C-183/00 Maria Victoria Gonzalez Sanchez v Medicina Asturiana ECR [2002] 1-3901.

87 See Joined Cases C-240/98 to C-244/98 Océano Grupo Editorial SA [2000] ECR I-4941 [hereinafter Océano Grupo].

88 See Fernanda Nicola and Evelyne Tichadou, 'Océano Grupo: Missed Opportunities and a Second Life for EU Consumer Law’ in Davies and Nicola (n 57) 369.

89 See $\mathrm{s}$ V. 


\section{Pointing at Progress}

A third move in our external critique reflects the more utopian side of CLS, which requires pondering what to do post-critique in order to achieve a more equitable and democratic society. Here, scholars may promote ideological progress through legal doctrines, legal education, or judicial and lawyering techniques. ${ }^{90}$ A more radical avenue is to show how legal reforms, no matter how well meaning, run out of steam if they are grafted onto larger systemic inequalities, ${ }^{91}$ which can only be addressed through a reconceptualisation of basic legal entitlements, ${ }^{92}$ transformative institutions, ${ }^{93}$ or ideological changes. ${ }^{94}$

This utopian vein characterises Hans-W Mickliz's reflections on the outcome of Aziz. ${ }^{95}$ This case, decided by a first chamber led by Vice-President Tizzano in the role of reporting judge, is one of the most acclaimed decisions rendered in the aftermath of the financial crisis. The answer of the CJEU amounted to what scholars called an 'earthquake. ${ }^{96}$ The Court held that the Spanish procedural rules impaired the level of protection required by the Unfair Terms Directive ${ }^{97}$ and provided, in line with the opinion of AG Kokott, concrete guidance on how to apply the tests of 'significant imbalance' and 'good faith.' ${ }^{98}$ The outcome of Aziz led to several important reforms of Spanish mortgage enforcement procedures. ${ }^{99}$ Most significantly it showed desperate consumers, on the verge of losing their homes and deeply resentful of EU-led austerity policies, that the Court does not ignore humanity. ${ }^{100}$

On the other hand, Micklitz has noted that defining standards of fairness is a much larger issue in an austerity-ridden Europe than the Aziz court was willing to concede. It is an issue that encompasses much more than the private law acquis, and calls for broader reflections on the meaning of social rights in the

90 See Bill Davies and Fernanda Nicola, 'Introduction to EU Law Stories' in Davies and Nicola (n 57) 1 .

91 Micklitz (n 62).

92 See Duncan Kennedy and Frank Michelman, 'Are Property and Contract Efficient?' (1980) 8 Hofstra Law Review 712.

93 See Karl Klare, 'Transformative Constitutionalism and the Common and Customary Law' (2010) 26 South African Journal on Human Rights 403.

94 See Gerald Frug, 'The City as a Legal Concept' (1980) 93 Harvard Law Review 1062.

95 See Case C-415/11 Mohamed Aziz v Caixa d'Estalvis de Catalunya, Tarragona i Manresa EU:C:2013:164.

96 Anthi Beka, 'The Ex Officio Doctrine in European Consumer Law: A Procedural Tool Reinvigorating Individual Consumer Litigation' (Doctoral thesis, University of Luxembourg, 2015) 341, 417.

97 Council Dir 93/13/EEC of 5 April 1993 on unfair terms in consumer contracts; Aziz (n 95) paras 57-59.

98 Aziz (n 95) paras 73-75.

99 The first round of reform was clearly insufficient to meet the standard of protection set by the Dir, as the Court found in Case C-169/14 Sánchez Morcillo and Abril García EU:C:2014:2099. More than a dozen references were lodged by Spanish courts in the aftermath of Aziz.

100 Beka (n 96). 
EU Charter. ${ }^{101}$ It is also problematic to let the Court be the sole social engineer in matters that require a much more robust and open democratic dialogue. While praising the court for 'getting it right' in the particular context of Aziz, and for enabling pro-debtor litigation strategies across the EU, Micklitz reminded readers that the problem of mortgage insolvency could be much better handled via a mix of judicial, legislative and administrative solutions. ${ }^{102}$ This is the sort of big-picture utopia that the CLS movement recommends, and that we hope to encounter more frequently in the academic commentary of CJEU decisions.

\section{Scholarship and the Challenge of Indeterminacy}

Foregrounding the distributive stakes of EU law disputes is clearly important when the judgment is cast in formalist terms, with unproblematic reference to the internal logic of the EU legal system. But identifying distributive issues is just as relevant when the court does engage in a balancing of conflicting rights or interests - a seemingly anti-formalist move-and yet portrays the stakes of the case as politically neutral, and eventually frames its result in the language of legal necessity. ${ }^{103}$ This was the decision-making move adopted by the CJEU in such cases as Laval (C-341/05) and Viking (C-438/05), both obviously linked to radical tensions between organised Nordic labour, employers and lower-wage workers coming from newly acceded Member States. ${ }^{104}$ In the aftermath of such judgments, a variety of commentators hurried to add texture to the court's analysis and to explain how, following the judgments, a particular vision of societal welfare had been asserted or reinforced. ${ }^{105}$

Competing accounts emerged. Some saw these cases as a regrettable triumph of shallow cosmopolitanism, as an undue challenge to hard-fought labourcapital equilibria, and as a worrisome dismantlement of national inter-class solidarity. ${ }^{106}$ Others looked at these disputes from the perspective of Central and Eastern Europe's job seekers and reached very different conclusions. This view

101 Micklitz (n 62).

102 ibid 12-18.

103 Lasser (n 41).

104 ibid. See also Stephen Weatherill, “Viking” and "Laval": The EU Internal Market Perspective' in Mark Freedland and Jeremias Prassl (eds), Viking, Laval and Beyond (Oxford, Hart Publishing, 2014) 36 (decrying the 'ambiguity of the Court'); Alexander Somek, 'Idealization, De-Politicization and Economic Due Process: System Transition in the European Union' in Bogdan Iancu (ed), The Law/ Politics Distinction in Contemporary Public Law Adjudication (Utrecht and Portland OR, Eleven International Publishing, 2009) 131, $140 \mathrm{ff}$ (criticising in particular AG Maduro's use of the notion of economic due process in his Viking opinion).

105 The literature is too vast to cite here.

106 See Alexander Somek, 'From Workers to Migrants, from Distributive Justice to Inclusion: Exploring the Changing Social-Democratic Imagination' (2012) 18 European Law Journal 711. 
emphasised that low-wage migrant workers were seeking not just free movement (an economic right), but also social rights (the right to work, the right to decent conditions), which were just as important as the social rights of the allegedly displaced Nordic workers. ${ }^{107}$ Still others followed the on-the-ground repercussions of such cases, tracing the ensuing arrangements between social partners in the affected states and economic sectors. ${ }^{108}$

The scholarly debate did not directly steer the court in one direction or another, but it made the crucial point that it was not possible for the Union to move forward without a thorough rethinking of labour-capital relations and without pondering, legally and politically, the distributive consequences of enhanced labour and capital mobility. The debate made clear, in other words, that the terse language of the EC Treaty on matters of free movement would not simply produce market efficiencies (if any), but would more likely trigger competition for finite resources and require a new political and philosophical arrangement. It also made clear that social and economic rights, as spelled out in primary and secondary EU law, would be simply the beginning of politically difficult conversations—not closing lines of cogent legal syllogisms.

Similarly situated at the crossroads of conflicting value choices is a more recent decision, Alo and Osso. ${ }^{109}$ The case revolved around the possibility for Syrian citizens, found worthy of subsidiary protection in Germany (though not yet eligible for refugee status), to pick and choose where exactly to settle in their host state. Here again, the Court found itself in the midst of conflicting considerations. On the one hand, the fact that both EU citizens and some categories of third-country nationals have the right to elect a place of residence, while subsidiary-protection recipients do not, is a form of discrimination, further complicating an already problematic distinction between 'mobile nationals and immobile aliens' in EU law. ${ }^{110}$ A firm judicial stance in favour of equal treatment should have led the court to allow these legal aliens to choose where to live. ${ }^{111}$ On the other hand, Germany was seeking a margin of flexibility in designing its immigration policy through a geographic restriction limited in time for those immigrants receiving public benefits. Foremost in the judges' minds were likely the media's images of Molenbeek, the neighbourhood where several of the terrorists behind recent attacks in Paris and Brussels were living, or the deeply disturbing news of riots between xenophobic locals and third-country nationals in many different EU cities. Allowing Member States to direct some of their immigrants to particular

107 Kukovec (n 16) 414-415.

108 See eg Eva Maria Tscherner, 'Austrian Labour Law after Viking, Laval, and Beyond' in Mark Freedland and Jeremias Prassl (eds), Viking, Laval and Beyond (Oxford, Hart Publishing, 2014) 125.

109 See Case C-443\&444/14 Alo and Osso EU:C:2016:127.

110 See Francesca Strumia, Supranational Citizenship and the Challenge of Diversity: Immigrants, Citizens and Member States in the EU (Leiden, Brill Academic Publishing, 2013) 105.

111 See Tamara Perišin, 'Transformation or Reconstitution of National Regulatory Policies at the EU Level: Insiders and Outsiders under Free Movement Rules' (in this volume). 
parts of the territory might in some cases foster the goal of cultural, social and economic integration as well as redistribute the fiscal burden evenly among German Länder. ${ }^{112}$ In the enormous body of literature comparing the available range of integration tools, Germany could certainly find support for the idea that all urban areas should remain diverse and should host carefully balanced mixtures of people of different backgrounds, especially given the state's allocation of resources for such purposes. ${ }^{13}$ The CJEU eventually decided to grant heavier weight to the latter considerations. The holding did narrow down the scope of Germany's policy choices, excluding that a Member State could mandate specific destinations for subsidiary protection beneficiaries on the sole basis of budgetary concerns. At the same time, the Court held that the state should retain the power to choose the migrants' place of residence if this proved necessary to the goals of integration and public safety-a result perhaps perceived as necessary at the time to quell anti-immigrant sentiment at the heart of Europe.

Cases like Viking, Laval, and Alo and Osso prove two points dear to CLS scholars. First, the distributive outcomes of adjudication are sometimes easy to identify as either progressive or regressive, but just as often they are really complicated, and may lead to disagreement even among scholars of equally progressive persuasion. The consequences of a judicial decision might remain under-determined, ${ }^{114}$ or even prove wholly ambivalent, due to rapidly changing historical circumstances (and the European Union is certainly experiencing a time of turbulence). ${ }^{115}$ Taking a stance may be difficult, and only partly possible. Utopian arguments put forth by legal academia may remain, indeed, utopian, and should be acknowledged as such. In some contexts, uncovering blind spots in the court's reasoning will be all that a scholar can do. As observed above, however, only an honest commentary informed by all relevant distributive possibilities can point in the direction of real progress.

Second, it is often the case that the law upon which judges must base their decision-be it black-letter law, a string of precedents, or relevant acquis-often 'runs out', and CLS's insight on the indeterminacy of legal rules should therefore be taken seriously. ${ }^{116}$ At the end of the day, many judicial decisions are based on one or another vision of the common good, and involve choices between often

112 See Alo and Osso (n 109) para 12 explaining that Germany was attempting: a) to equalise the fiscal burdens of the different Länder receiving the refugees; b) to '[avert the] emergence of points of social tensions'; and c) to '[link] foreign nationals in particular need of integration to a specific place of residence so that they can avail themselves of the integration facilities available there'.

113 Integration policies in the EU may even draw inspiration from crucial conversations on racial justice in the US. See eg Fisher v University of Texas at Austin 133 S Ct 2198 (2016).

114 See Oliver Wendell Holmes, 'Privilege, Malice and Intent' (1894) 8 Harvard Law Review 1.

115 See Pierre Schlag (n 56) (addressing the plurality of context).

116 See Mark Kelman, A Guide to Critical Legal Studies (Cambridge, Harvard University Press, 1987) (outlining the controversy on law's indeterminacy within the CLS movement). of Perišin (n 111), suggesting a more univocal account of the effects of decisions like Alo and Osso. 
irreconcilable world views. Even though judges cast their reasoning in terms of legal necessity, ${ }^{117}$ no univocal conclusion can be reached in such disputes simply on the basis of legal rules and principles (free movement, non-discrimination, individual rights, international obligations, etc), which remain ultimately open-ended. This realisation can be painful, ${ }^{118}$ not only for judges duly preoccupied with maintaining an aura of sheer objectivity, but also for progressive advocates, who would rather present their own argument as being clearly superior in point of law. ${ }^{119}$ The realisation of law's indeterminacy, however, is often a necessary starting point for serious distributive analysis in scholarly circles. Progressive scholars are best positioned to voice the inner limits of legal argumentation, to aid the Court in identifying gaps, conflicts and ambiguities in the law, and hopefully to promote distributive justice and inclusion as paramount goals of the EU legal system. Only by acknowledging 'the inevitability of value-laden choice in adjudication' ${ }^{120}$ will legal scholars engage the Court in a continuous dialogue about values and perhaps, by so doing, move forward the ball of substantive justice.

117 Karl Klare, 'Critical Perspectives on Social and Economic Rights: Democracy and Separation of Powers' in Alviar García, Klare and Williams (eds) (n 63) 3 (noting that 'the decision-maker's judgment is a performance enacted to persuade the public that the outcome was required by legal necessity').

$118 \mathrm{ibid}$. ('Acknowledging that ethical and political choice play a role in adjudication is problematic in legal cultures that socialize participants to believe that such influence is illegitimate.').

119 ibid.

120 ibid. 